\title{
Geographical and Level of Local Government Variation on the Phenomenon of Ecological Footprint in Indonesia: Descriptive Analysis
}

\author{
Muhammad Abduh $^{1 *}$, Dedik Budianta ${ }^{2}$, Arinafril ${ }^{3}$, Lili Erina ${ }^{4}$ \\ ${ }^{1}$ Ilmu Pemerintahan, Program Pascasarjana, Universitas Tamansiswa, Palembang \\ ${ }^{2}$ Ilmu Lingkungan, Program Pascasarjana, Universitas Sriwijaya \\ ${ }^{2}$ Ilmu Lingkungan, Program Pascasarjana, Universitas Sriwijaya \\ ${ }^{4}$ Ilmu Administrasi Negara, Fakultas Ilmu Sosial dan Ilmu Politik, Universitas Sriwijaya \\ *Corresponding Author: abduh.muhammad@gmail.com

\begin{tabular}{llll} 
Article history & & & \\
\hline Received & Received in revised form & Accepted & Available online \\
02 July 2019 & 10 December 2019 & 27 December 2019 & 30 December 2019 \\
\hline
\end{tabular}

\begin{abstract}
To simplify the description of the damage phenomenon to the earth, the concept of ecological footprint can be used. This concept is not specifically built to calculate the destruction of the earth. This concept calculates how much space (land and water) humans need to produce the resources they need including absorbing the waste they produce. This study calculates Indonesia's ecological footprint by observing variations according to geography and the level of regional government. This research uses the Environmental Care Behavior Survey Year 2013, Village Potential Census Year 2011 and the 2013 National Social Welfare Survey, or SUSENAS. All were surveyed by the Indonesian Central Bureau of Statistics. As a result, Indonesia's ecological footprint is $1.51 \mathrm{gha}$. At the provincial level, the ecological footprint of Jakarta is the highest compared to other provinces' of 1.84 gha. While East Nusa Tenggara has the lowest ecological footprint, which is 1.30 gha. Indonesia's ecological footprint follows the general pattern in the world, of higher ecological footprint in urban area compared to other types of regions such as villages, watersheds, beaches, mountains, forests or hilly areas.

Keywords: ecological footprint, geographical, local government, Indonesia.
\end{abstract}

Abstrak (Indonesian): Untuk menyederhanakan gambaran fenomena kerusakan wajah bumi, dapat dipergunakan konsep jejak ekologi. Konsep ini tidak secara khusus dibangun untuk menghitung kerusakan wajah bumi. Konsep ini menghitung seberapa banyak ruang (di darat dan air) yang dibutuhkan manusia untuk menghasilkan sumber daya yang mereka perlukan termasuk menyerap limbah yang mereka hasilkan. Penelitian ini menghitung angka jejak ekologi Indonesia dengan memperhatikan variasi menurut geografi dan level pemerintahan daerah. Penelitian ini menggunakan data Survei Perilaku Peduli Lingkungan tahun 2013, Survei Sosial dan Ekonomi Nasional (Susenas) 2013 dan pendataan potensi desa (Podes) tahun 2011 yang dipersiapkan oleh Badan Pusat Statistik Indonesia. Hasilnya, jejak ekologi Indonesia adalah 1.51 gha. Di level provinsi, jejak ekologi DKI Jakarta merupakan yang tertinggi dibanding provinsi lain, yaitu 1,84 gha. Sementara Nusa Tenggara Timur memiliki jejak ekologi terendah, yaitu 1,30 gha. Angka jejak ekologi Indonesia mengikuti pola umum di dunia, yakni angka jejak ekologi kota selalu lebih tinggi dari tipe wilayah lain seperti desa, daerah aliran sungai, pantai, pegunungan, sekitar hutan ataupun daerah perbukitan.

Katakunci: jejak ekologi, geografi, pemerintah daerah, Indonesia

\section{Introduction}

To help simplifying the description of the damage phenomenon to the earth, the concept of ecological footprint can be used. Actually this concept is not specifically built to calculate the destruction of the earth. Through Ecological footprint and appropriated carrying capacity: what urban economics leaves out, [1] began to popularize the concept of ecological footprint. This concept calculates how much space (land and water) humans need to produce the resources they need including absorbing the waste they produce. The calculation of the ecological footprint is carried out by calculating the number of hectares of living space (land and water) on earth that is needed by its inhabitants (human) to fulfill all of its necessities in years.

The concept of ecological footprint can be interpreted as how wasteful an individual's and society's lifestyle is in a particular country. [2] reveals the level of wasteful use of natural resources by countries in the world. There are ten countries that have the highest ecological footprint (wasteful) when utilizing their natural resources, namely: Qatar, Kuwait, United Arab Emirates, Denmark, the United States, Belgium, Australia, Canada, the Netherlands and Ireland. In the report, it was revealed that the progress of several countries in the economic field had increased the ecological footprint per capita by 65 percent since 1961. This means that an increase in 
the ecological footprint was in line with the economic progress of a country. Furthermore, the Living Planet Report 2012 noted that the lifestyle of the Qatarians needs to be supported by natural resources of up to 11.68 hectares, the Japanese with 4.17 hectares and the Indonesians with only 1.13 hectares. Meanwhile, the lifestyle of the people of Bangladesh and Timor Leste is fulfilled with only 0.66 and 0.47 hectares.

This ecological footprint can be used in a variety of analytical units, ranging from the smallest to the largest. Lambrechts and Liedekerke [3] argue that many ecological footprint analyzes have been carried out in various entities, both private, public, and non-governmental organizations, including educational institutions at various levels such as: personal, organizational, urban, regional, and state. This study calculates Indonesia's ecological footprint by observing variations according to geography and the level of local government.

\section{Methods}

This research uses the Environmental Care Behavior Survey Year 2013, Village Potential Census Year 2011 and the 2013 National Social Welfare Survey, or SUSENAS which were surveyed by the Indonesian Central Bureau of Statistics. The coverage of the 2013 Environmental Care Behavior Survey is all regencies/cities in Indonesia with sample of 75,000 households with 271,019 household members. The types of data collection include: i) information on household members, ii) housing conditions, iii) habits of energy use, iv) behavior of collecting, managing and utilizing waste, v) habit in using and treating water. On the other hand, village potential census data has so far been the only thematic spatial data source to show the possibility of village- level areas across Indonesia. Village potential census was designed based on the condition of December 2009 which consisted of 77,126 villagelevel spread over 6,651 sub-districts in 497 districts. The SUSENAS is a national survey consisting of 300,000 respondents, and is representative for each of Indonesia's 497 districts. Ecological footprint is measured through six main criterias, those are: a) housing arrangement, b) energy utilization, c) waste management, d) water utilization, e) transportation use and f) consumption of food and beverages. We adopted a method by Turner [4] to weight each behavior by adding all the values and dividing it by 100 in units of hectares.

\section{Results and Discussion}

Table 1 describes the ecological footprint in Indonesia with various variations such as ecological footprint according to island, province, urban - rural and certain geographic environmental conditions. In addition to the average ecological footprint, there are several notes that need to be underlined. The mean and median values of exactly the same value are found on the island of Sumatra. That is, before calculating the value of skewness and kurtosis, symmetrical data is only found in Sumatra.

However, there are many mean and median values with only 0.1 difference. This means that the data is almost symmetrical. Sumatra kurtosis value is 3.3 - meaning that the data condition is rather sharp. Meanwhile, the skewness value of 0.3 means normal, almost symmetrical and stretches to the right away from the average value. Almost all kurtosis values are in position around the number three, meaning that the distribution of this data is almost normal (mesokurtic). Likewise the mean, mode and median values are in the same position. This shows that this data is classified as having a sismetric frequency distribution curve.

The average number of Indonesia's ecological footprint is $1.51 \mathrm{gha}$. This figure is above the 2012 Indonesian figure calculated by the World Wide Fund Team, which is 1.13 gha as in Grooten [2]. Differences in ecological footprint can occur because the basic data used was different. The ecological footprint calculated by the World Wide Fund Team used baseline data in 2008 and was calculated in 2012. While the ecological footprint from the results of this study uses baseline data in 2013. In addition, differences can occur because there are many meaningful changes within 5 years. According to [2] the ecological footprint is very dependent on the level of development and wealth. Wealth is related to what is consumed, what products are purchased and the pattern of travelling. In addition, decisions taken by the government and business people also constitute a substantial determinant of the ecological footprint. For example, the policy of government administrators in the use of energy sources can be a determinant of the high and low ecological footprint. The phenomenal Indonesian government policy in 20072010 was the conversion of kerosene to liquid petroleum gas (LPG) which had not been effective.

Uddin [5] conducted research by examining the effect of real income, financial development and trade openness on ecological consumption. One result shows a positive and significant relationship between ecological footprint and real income where the higher the income the higher the ecological footprint. According to the Central Bureau of Statistics Republic of Indonesia [6], the Gross Domestic Product Per Capita in 2008 was 21,364,354.10 rupiah, while in 2013 it was 36,508,486.32 rupiah. This means that there has been an increase in Gross Domestic Product Per Capita in 2008-2013 of $70.88 \%$. If using the analogy of the findings Uddin [5], the increase in income will increase the ecological footprint which is a common practice. 
Table 1 Ecological footprint in Indonesia

\begin{tabular}{|c|c|c|c|c|}
\hline Area & Mean & Median & Skewness & Kurtosis \\
\hline Indonesia & 1.51 & 1.51 & 0.208 & 3.299 \\
\hline \multicolumn{5}{|l|}{ Island } \\
\hline Sumatera & 1.54 & 1.53 & 0.309 & 3.394 \\
\hline Jawa - Bali & 1.54 & 1.53 & 0.339 & 3.312 \\
\hline Kalimantan & 1.57 & 1.57 & 0.182 & 3.489 \\
\hline Sulawesi & 1.41 & 1.40 & 0.334 & 3.268 \\
\hline Papua-Maluku-Nusatenggara & 1.45 & 1.46 & -0.068 & 2.907 \\
\hline \multicolumn{5}{|l|}{ Level of government } \\
\hline Urban (Kelurahan) & 1.61 & 1.59 & 0.207 & 3.039 \\
\hline Rural & 1.49 & 1.49 & 0.134 & 3.264 \\
\hline \multicolumn{5}{|l|}{ Flowing river } \\
\hline Yes & 1.50 & 1.49 & 0.299 & 3.284 \\
\hline No & 1.51 & 1.51 & 0.181 & 3.291 \\
\hline \multicolumn{5}{|l|}{ Land conditions } \\
\hline Hamparan & 1.52 & 1.52 & 0.235 & 3.286 \\
\hline Puncak-lereng-lembah & 1.49 & 1.49 & 0.088 & 3.211 \\
\hline \multicolumn{5}{|l|}{ Land slope } \\
\hline$<15$ derajat & 1.53 & 1.52 & 0.228 & 3.242 \\
\hline$\Rightarrow>15$ derajat & 1.49 & 1.49 & 0.158 & 3.385 \\
\hline \multicolumn{5}{|l|}{ Forest area } \\
\hline Outside the forest & 1.53 & 1.52 & 0.239 & 3.321 \\
\hline Inside / edge of the forest & 1.48 & 1.49 & 0.108 & 3.187 \\
\hline \multicolumn{5}{|l|}{ Coastal area } \\
\hline Yes & 1.46 & 1.45 & 0.205 & 3.255 \\
\hline No & 1.54 & 1.53 & 0.226 & 3.332 \\
\hline \multicolumn{5}{|l|}{ Province } \\
\hline South Sumatera & 1.54 & 1.53 & 0.307 & 3.298 \\
\hline Jakarta & 1.84 & 1.85 & 0.020 & 2.922 \\
\hline West Kalimantan & 1.56 & 1.56 & 0.172 & 3.452 \\
\hline Gorontalo & 1.34 & 1.33 & 0.220 & 3.166 \\
\hline East Nusatenggara & 1.30 & 1.30 & 0.102 & 2.481 \\
\hline
\end{tabular}

Source: Prepared from SPPLH2013, SUSENAS2013, PODES 2011 BPS

The usual development phenomenon is marked by an increase in energy. Research conducted by [7] in oil-producing Middle Eastern and North African countries shows that energy use has exacerbated the ecological footprint while real Gross Domestic Product per capita shows an inverted U-shaped relationship with the ecological footprint following the Kuznets environmental curve (Figure 1).

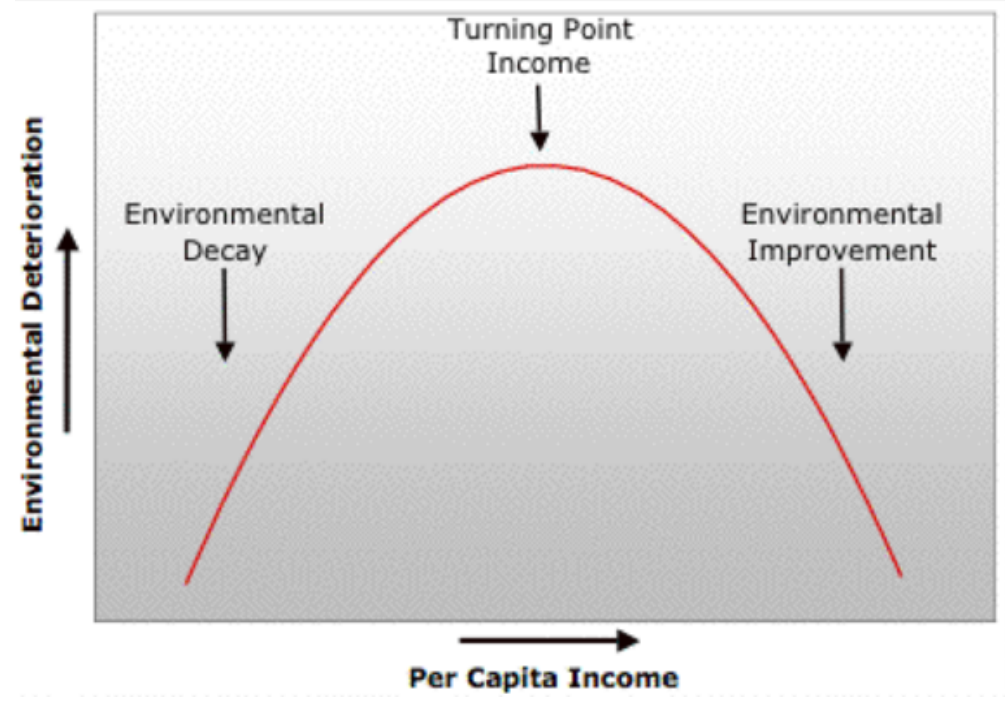


Figure 1: Kuznets environmental curve (Yandle et al., 2014)

This means that in the early days of development and the development process, the ecological footprint will increase due to energy use and pollution. To a certain extent, development is considered successful because it has increased income, easy access to health, education and employment. In this condition, awareness of the importance of a healthy environment will grow, and in time it will process and result in a decrease in ecological footprint.

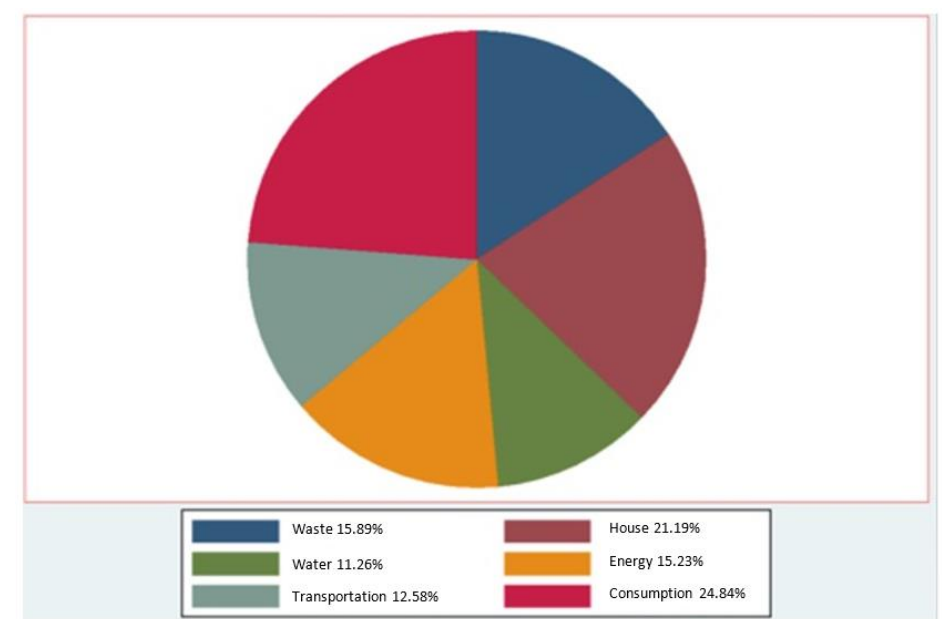

Figure 2. The proportion of 6 elements in composing an ecological footprint Source: Prepared from SPPLH2013, SUSENAS2013, PODES 2011 BPS

From sociologists such as Davidson and Stedman [8], U inverted means to reflect for improvement. In the language of Qur'an the inverted $\mathrm{U}$ - can be interpreted as returning to the right path after doing damage on land and at sea (QS, Ar-Ruum, 41). The process of returning to the right path can be started by referring to the ecological footprint itself which functions as a mirror. As shown in Figure 2, the priority of change can be started from the pattern of eating and drinking. Food and beverages are the biggest element in forming an ecological footprint that is $24.84 \%$, followed by housing arrangements, waste management, energy use, transportation use and water utilization. The basis for change can use one of the ideas of the Creator like "... eat and drink you, and do not overdo it. Verily Allah does not like the people who are overrated " (QS. Al-A'raaf: 31).

By using academic language, the scriptures can be positioned as scientific law. Davis and Carter [9] concluded that overeating has similarities with drug addiction. This conclusion is based on comparable clinical trials, the biological mechanisms and the evidence that the two disorders share the same characteristics. By placing paragraph 31 of QS. Al A'raaf as scientific law, it can be derived from other aspects, not only applied to food, but to all natural resources such as energy, water and air. Thus, the recommendation to use water as needed or use enough energy will be a social norm.

The use of the holy verse as a behavioral reference is still well preserved at all ages, including young people. Arli [10] observed the impact of religiosity on consumer ethics among young people. The results of his research mention that young people understand the boundary between legal and illegal behavior. But if the legal and illegal boundaries are not clear, they use religious law as a hand. This means, religious practices are still strong among young people. Reflecting on the religiosity of these young people, then using religious ideas among young people as a reference to maintain conditions so that the ecological footprint remains low is not impossible. The basic idea is to consume natural resources without exaggeration as outlined by the holy verse.

The link between religiosity and the environment is still not a popular topic and very few in number. Among those few, [11] examined the environmental impact of popular religious tourism in Mashhad, Iran. In particular, this study assessed the spatial pattern of environmental impacts from religious tourism with a focus on the area around the sanctuary. As a result, although religious tourism has resulted in environmental improvements, it is limited to areas that immediately surround the sanctuary, and this improvement does not cover the entire city. Thus, incorporating ideas about the environment needs to be included in discussions about religious life. Hopefully, the growing awareness of environmental conditions will reduce the ecological footprint.

From Table 1, we can also find the phenomenon of two administrative regions that have an ecological footprint far above the average value of urban areas and Jakarta. This is understandable because cities (including Jakarta) are very dense areas that require very high resources compared to 
other types of regions. Such conditions evenly occur 3.1. Ecological footprint of urban - rural

According to Muñuzuri [12] the high rate of ecological footprint in urban areas is mainly caused by high consumption for transportation, traffic congestion, lack of parking and uncontrolled pollution. Geng [13] added that the high ecological footprint in urban areas is caused by industries that are not well managed. In a study comparing the conditions of the ecological footprint of the two sister cities between Shenyang-China and Kawasaki-Japan, the data analysis was based on data from 1997 to 2009. The results showed that the Shenyang ecological footprint experienced a significant in all medium and large cities in the world.

increase, while the figures Kawasaki is quite stable, even though the per capita income figure in Shenyang is much lower than Kawasaki. To further enhance sustainable development, Shenyang must collaborate with Kawasaki, learn about the economic experience of Kawasaki city and other environmental management experiences. In addition, Shenyang must also learn from other leading cities and try to optimize its industrial and energy structure through increasing awareness of the citizens' environment so that they can move towards a more sustainable development direction.

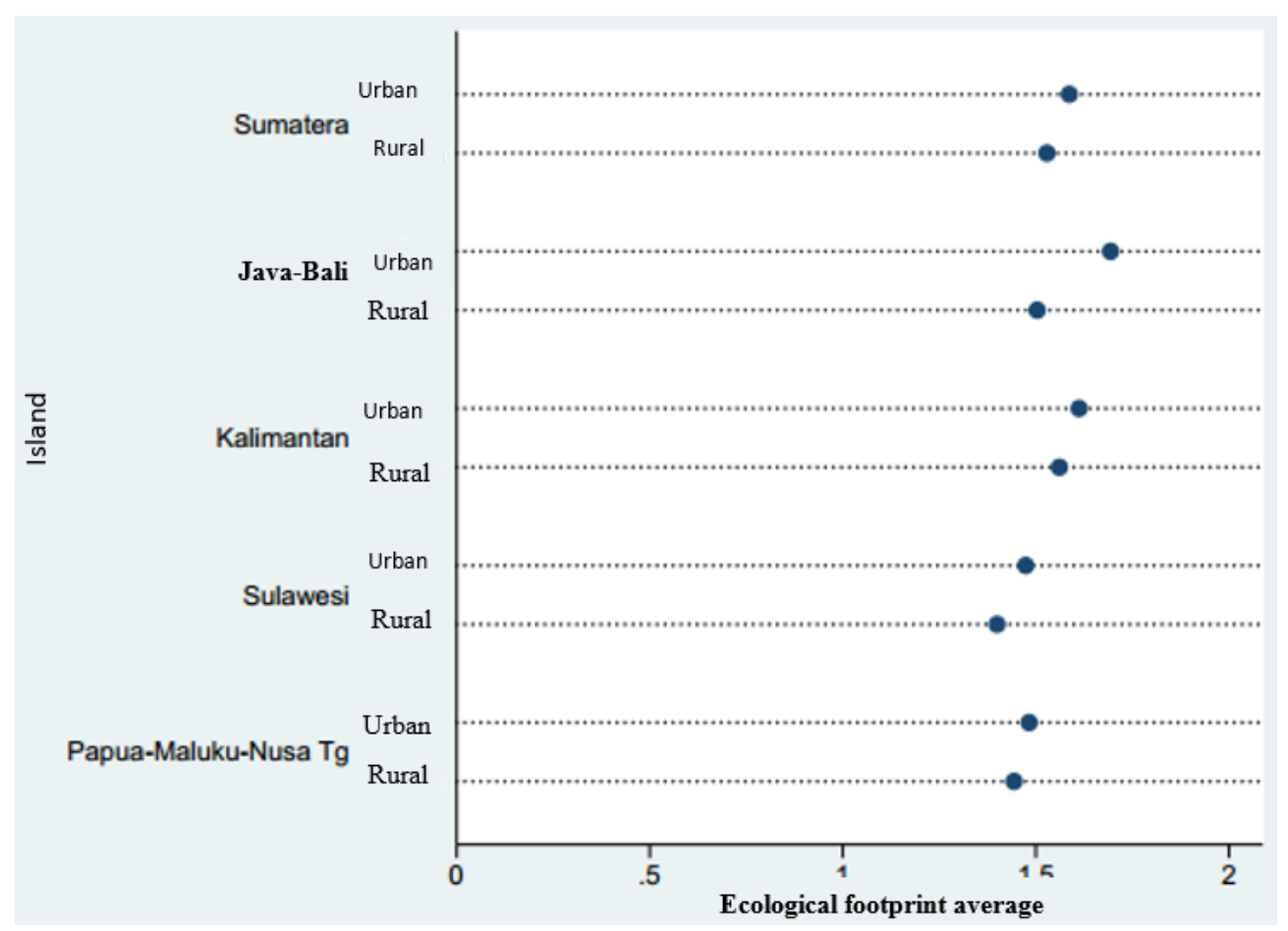

Figure 3: Average ecological footprint of urban-rural on the main island in Indonesia Source: Prepared from SPPLH2013, SUSENAS2013, PODES 2011 BPS

Ecological footprint is identical to the city phenomenon. That is, the urban ecological footprint is always higher than the countryside. Figure 3 provides evidence. Ecological footprint in cities on all islands in Indonesia is always higher than the ecological footprint in the countryside. Following the thinking of Pellizzoni [14] which states that the concept of matter of environmental sociology is allegedly still in a dormant state, the ecological footprint can contribute to clarifying the concept of matter of environmental sociology. The phenomenon of ecological footprint in city countries like Taiwan can be a mirror for reflection. Wang [15] stated that in 2007 due to the consumptive lifestyle of Taiwanese people, the provision of natural resources normally consumed by Taiwanese people needed to be supported by 42 times the area of Taiwan.

Reflecting on the condition of Taiwan's ecological footprint in 2007 and the existence of a similar pattern on the ecological footprint on all the main islands in Indonesia, the city's ecological footprint is always higher as shown in Figure 4. Consumptive culture needs to be transformed, because consumption is compulsory. Perhaps just enough consumption as exemplified by the preceding generation, needs to be echoed again.

\subsection{Ecological footprint of the coastal area}

Using the urban-rural ecological footprint as a reference, the ecological footprint along the coast on 
all islands in Indonesia is always lower than in other regions as shown in Figure 4. In other words, the consumer culture in the coastal area is lower than other regions. In the social sciences, beach culture is better known as coastal culture. According to Baabou [16], the difference in ecological traces between coastal cities is caused by culture. Coastal culture is a major driver of food consumption, transportation and consumption of manufactured goods. This researcher calculates ecological footprint in 19 coastal cities in the Mediterranean region. Valletta, Athens, and Genoa are cities with the highest ecological footprint, ranging between 5.3 and 4.8 gha. While Tirana, Alexandria and Antalya have the lowest ecological footprint, ranging between 2.1 and 2.7 gha. Most of the ecological footprint in the city exceeds their countries except Thessaloniki, Tel Aviv, Venice, Palermo and Naples.

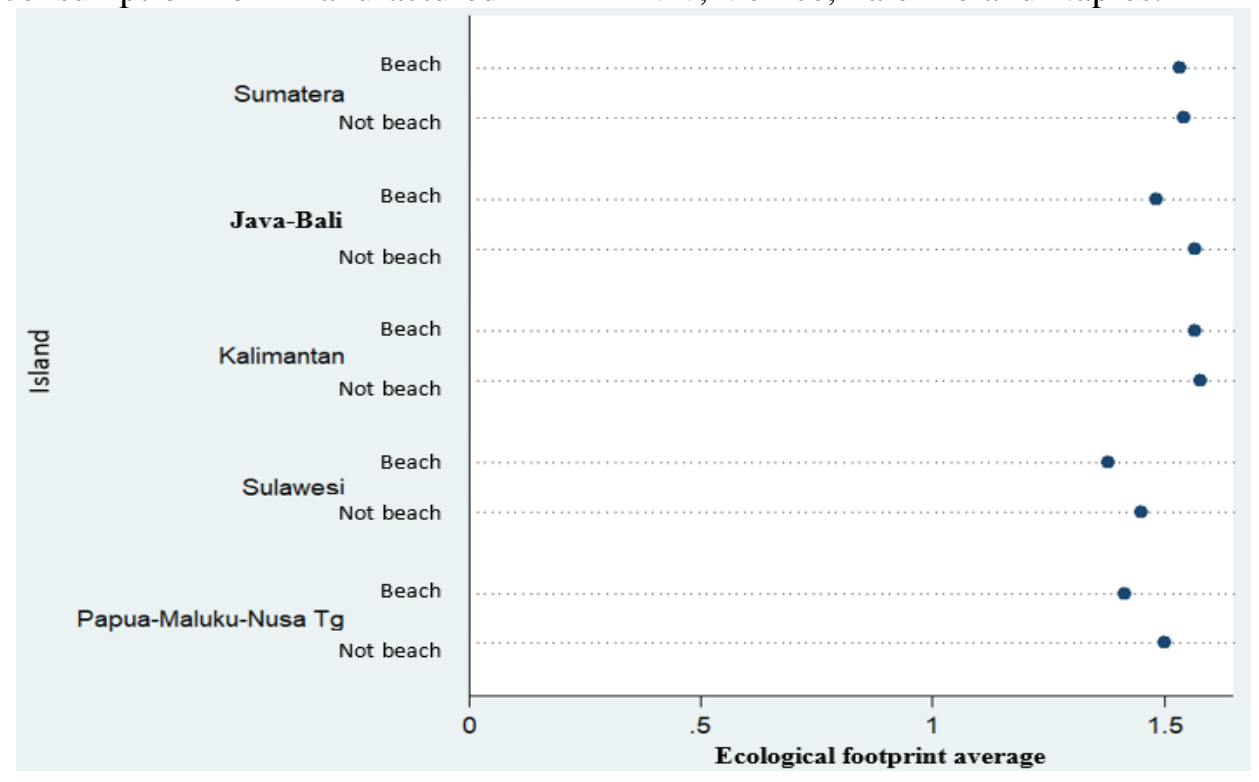

Figure 4: Average coastal ecological footprint on the main island in Indonesia Source: Prepared from SPPLH2013, SUSENAS2013, PODES 2011 BPS

\subsection{Ecological footprint of river areas}

Figure 5 shows the ecological footprint in the area where the river passes. Except in Sulawesi and Papua-Maluku-Nusatenggara, the ecological footprint in the areas traversed by rivers in Sumatra, Java-Bali and Kalimantan is always lower than those that are not traversed by rivers. That is, the use of natural resources in the area around the river in the three islands is lower than the area that is not traversed by the river.

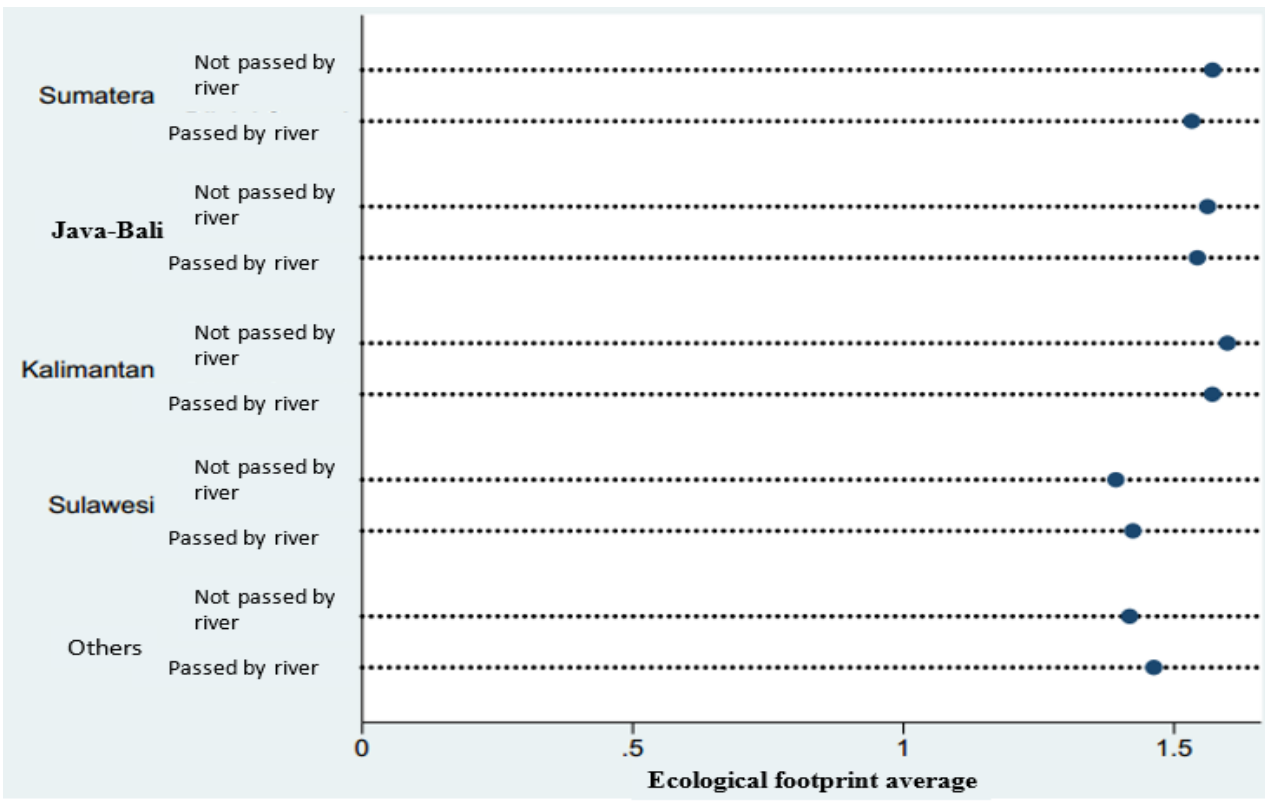

Figure 5: Average river areas ecological footprint on the main island in Indonesia Source: Prepared from SPPLH2013, SUSENAS2013, PODES 2011 BPS 
Ecological footprint along the river area cannot be separated from development. Li and Wen [17] propose the development of ecological corridors along the watershed by giving attention to the cooperation of all stakeholders. By strengthening collaboration among stakeholders, the development of ecological corridors will save many things which will ultimately save natural resources.

\subsection{Ecological footprint of forest area}

Figure 6 provides evidence that the ecological footprint tends to be urbanized. Except in forest areas in Papua-Maluku-Nusatenggara, the ecological footprint in all forest areas in Sumatra, Java-Bali, Kalimantan and Sulawesi is always lower than the ecological footprint outside the forest area. In the view of Toth and Szigeti [18] the ecological footprint is always related to the concentration of the population. Most of the population chooses to live outside the forest area so that the ecological footprint in the forest area is lower than outside the forest area. In other words, the lifestyle and consumption culture in the area around the forest needs to be maintained and even disseminated.

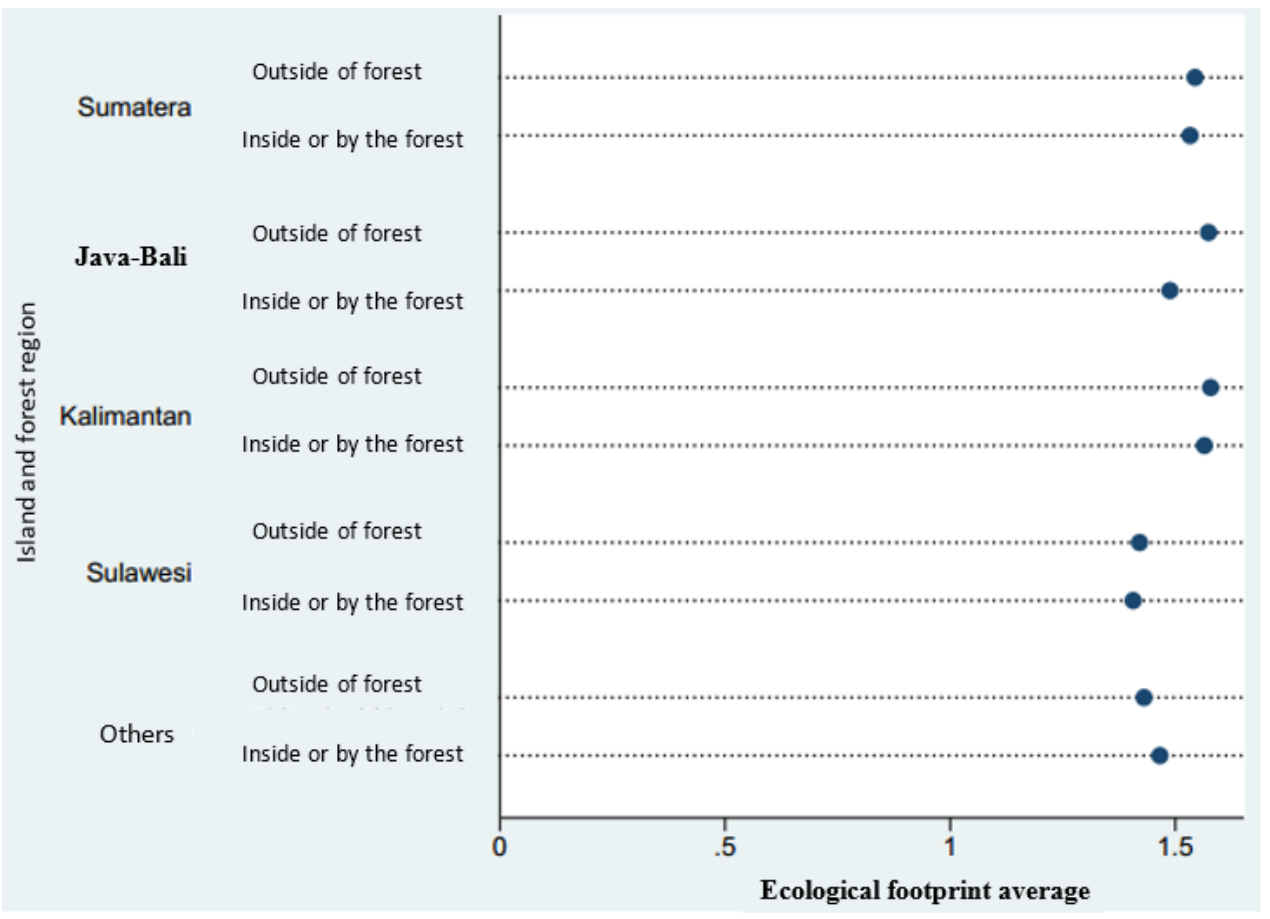

Figure 5: Average forest areas ecological footprint on the main island in Indonesia Source: Prepared from SPPLH2013, SUSENAS2013, PODES 2011 BPS

\subsection{Ecological footprint of $\geq 15$ degrees land slope area}

The $\geq 15$ degrees slope of the land is an unstable condition. Treatment of land like this requires higher awareness so as not to endanger. Logically, the ecological footprint in an area that has a slope of $\geq 15$ degrees will be lower than the slope of $<15$ degrees. Figure 6 shows that except in Sumatra, the ecological footprint in an area with a land slope of $\geq 15$ degrees is always lower than that of an area that has a slope of $<15$ degrees. This phenomenon is a sign that consumption in an area with a slope of $\geq 15$ degrees is more measurable. This is likely related to awareness gained from natural events where the area located on the slope of $\geq 15$ degrees is more vulnerable to disasters. Referring to the opinion of Comino [19] that the type of field (land) and cultivation system are determinants of erosion and vegetation. Thus, awareness of the impact of disasters is very important. The implication, when awareness of the impact of disaster reduction (eg. erosion) can be a reference that can prevent erosion. With this kind of awareness indirectly will make a low ecological footprint. 


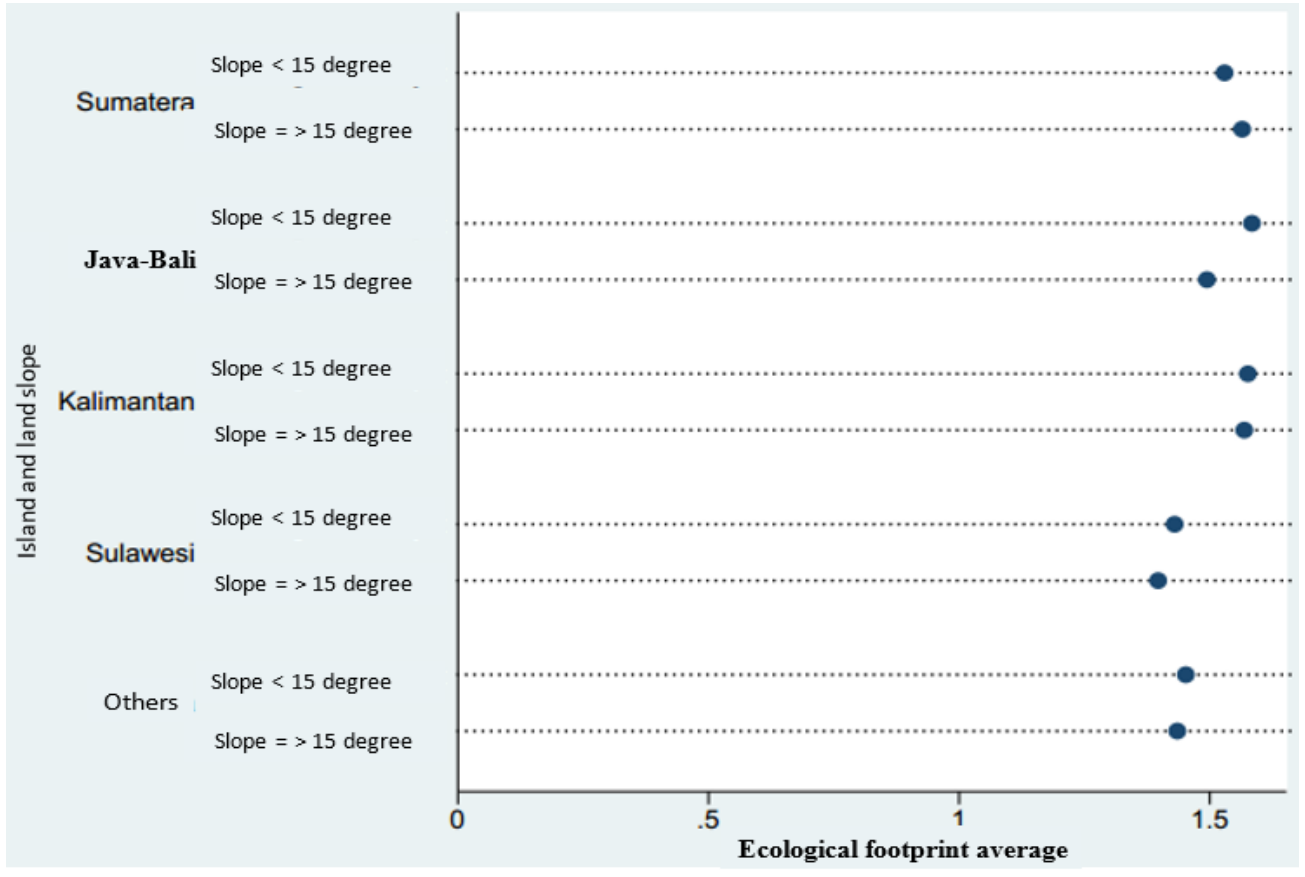

Figure 6: Average land slope $\geq 15$ degrees ecological footprint on the main island in Indonesia Source: Prepared from SPPLH2013, SUSENAS2013, PODES 2011 BPS

\subsection{Ecological footprint of the top-slope-valley area}

From a vulnerability point of view, the area of the slopes is almost the same as the condition of the land with a slope of $\geq 15$ degrees. Figure 7 provides a number of ecological footprints in the valley slopes. In Sumatra, Java-Bali and Sulawesi the ecological footprint in the valley-slopes is lower than the ecological footprint on the stretch. Whereas in
Kalimantan and Papua-Maluku-Nusatenggara the opposite occurs. For a phenomenon like this, Chu [20] use the term unstable. Regional instability like this if not managed properly and carefully will lead to a serious ecological security situation. This conclusion was obtained by Chu [20] after examining ecological security based on the ecological footprint in Beijing-Tianjin-Hebei region, China.

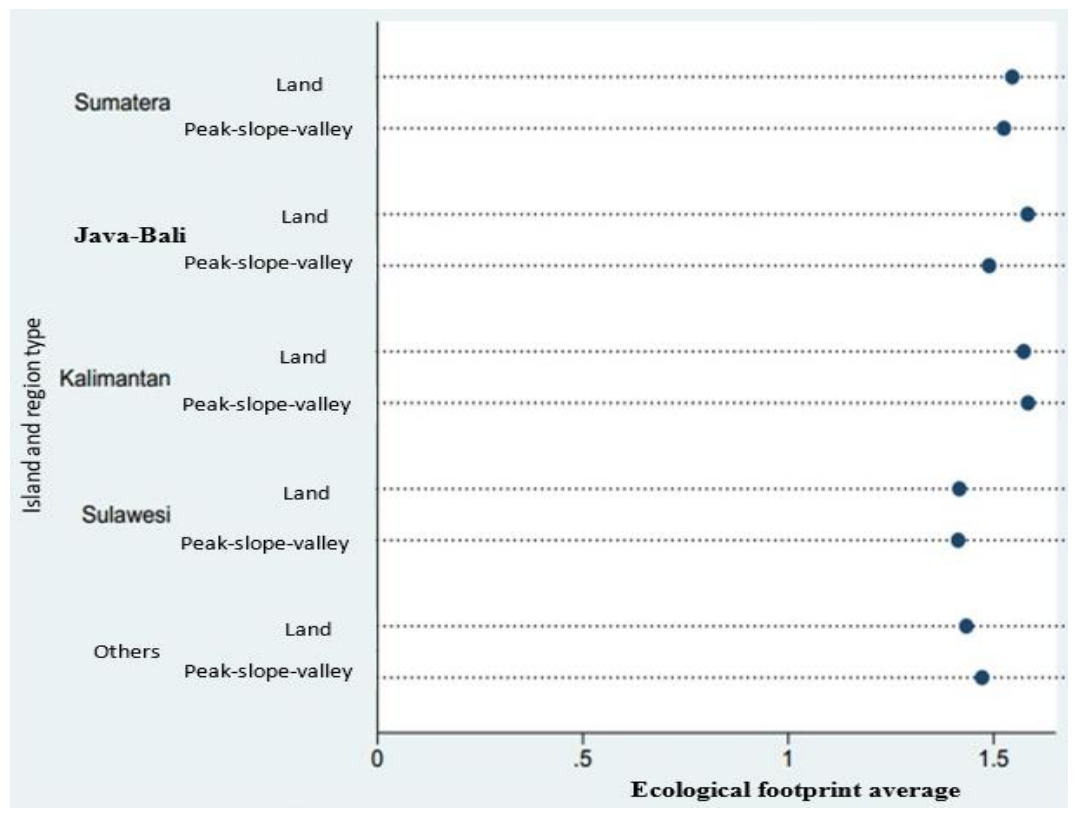

Figure 7: Average the top-slope-valley ecological footprint on the main island in Indonesia Source: Prepared from SPPLH2013, SUSENAS2013, PODES 2011 BPS Ecological footprint 
Ecological security can be achieved if there is a balance between economic development and ecosystem conservation. According to Chu [20], the ecological security of the Beijing-Tianjin-Hebei region (BTH) between 1995 and 2010 cannot be maintained based on the ecological footprint of the BTH region increasing to 1.77 times. Using the ecological security phenomenon of the Beijing-Tianjin-Hebei region as a material for sociological reflection will have implications for the importance of taking care of unstable lands more seriously to avoid a scary environmental disaster.

\section{Conclusion}

Indonesia's ecological footprint is $1.51 \mathrm{gha}$. This figure is higher than the figure produced by WWF. The biggest contribution comes from the consumption of food and beverages and followed by the management of the house. This difference can occur for at least two things: First, there is a difference in the basic data. WWF used 2008 data, while this study used baseline data in 2013. Second, over a period of five years there have certainly been many changes in various things. The most easily measured is the increase in Indonesia's Gross Domestic Product per Capita in 2008-2013 by $70.88 \%$. Increased ecological footprint cannot be avoided. However, the increase needs to be watched carefully.

Kalimantan Island has the highest ecological footprint, while Sulawesi has the lowest ecological footprint. The ecological footprint of Jakarta is the highest compared to all regional units, while East Nusa Tenggara has the lowest ecological footprint. Indonesia's ecological footprint follows the general pattern in the world, namely the rate of urban ecological footprint is always higher than other types of regions such as villages, watersheds, beaches, mountains, forests or hilly areas. The ecological footprint of 3 islands, namely Sumatra, Java-Bali and Kalimantan is higher than the national average, while the two main islands, Sulawesi and others, are below the national figure. If it is considered according to the regional typology, the number of ecological footprint that is higher than the national average can be found in areas classified as not peak-slope areas, not including areas that have a slope of $\geq 15$ degrees, not areas within / edge of the forest and not an area that has a beach.

\section{References}

[1] Rees, W. E. (1992). Ecological footprints and appropriated carrying capacity: what urban economics leaves out. Environment and urbanization, 4(2), 121-130.

[2] Grooten, M., Almond, R., \& McLellan, R. (Eds.). (2012). Living planet report 2012: Biodiversity, biocapacity and better choices. World Wide Fund for Nature.
[3] Lambrechts, W., \& Van Liedekerke, L. (2014). Using ecological footprint analysis in higher education: Campus operations, policy development and educational purposes. Ecological Indicators, 45, 402-406.

[4] Turner, T. How Big is My Ecological Footprint? In Grant, T., \& Littlejohn, G. (Eds.). (2005). Teaching Green--The Elementary Years: Hands-on Learning in Grades K-5. New Society Publishers.

[5] Uddin, G. A., Salahuddin, M., Alam, K., \& Gow, J. (2017). Ecological footprint and real income: Panel data evidence from the 27 highest emitting countries. Ecological Indicators, 77, 166-175.

[6] Badan Pusat Statistik, Produk Domestik Bruto Per Kapita, Produk Nasional Bruto Per Kapita dan Pendapatan Nasional Per Kapita, 2000-2013 (Rupiah), https://www.bps. go.id/index.php/linkTabelStatis/1241, diakses 12 Desember 2017.

[7] Charfeddine, L., \& Mrabet, Z. (2017). The impact of economic development and social-political factors on ecological footprint: A panel data analysis for 15 MENA countries. Renewable and Sustainable Energy Reviews, 76, 138-154.

[8] Davidson, D. J., \& Stedman, R. C. (2017). Calling forth the change-makers: Reflexivity theory and climate change attitudes and behaviors. Acta Sociologica, 0001699317693065.

[9] Davis, C., \& Carter, J. C. (2009). Compulsive overeating as an addiction disorder. A review of theory and evidence. Appetite, 53(1), 1-8.

[10] Arli, D., Arli, D., Tjiptono, F., Tjiptono, F., Lasmono, H., Lasmono, H., ... \& Anandya, D. (2017). Do consumer ethics and consumer religiousness evolve across time? Insights from Millennials in Indonesia. Young Consumers, 18(4), 329-347.

[11] Alipour, H., Olya, H. G., \& Forouzan, I. (2017). Environmental Impacts of Mass Religious Tourism: From Residents' Perspectives. Tourism Analysis, 22(2), 167-183.

[12] Muñuzuri, J., Van Duin, J. H. R., \& Escudero, A. (2010). How efficient is city logistics? Estimating ecological footprints for urban freight deliveries. Procedia-Social and Behavioral Sciences, 2(3), 6165-6176.

[13] Geng, Y., Zhang, L., Chen, X., Xue, B., Fujita, T., \& Dong, H. (2014). Urban ecological footprint analysis: a comparative study between Shenyang in China and Kawasan Japan. Journal of cleaner production, 75, 130-142.

[14] Pellizzoni, L. (2016). Catching up with things? Environmental sociology and the material turn in social theory. Environmental Sociology, 2(4), 312-321. 
[15] Wang, B. C., Chou, F. Y., \& Lee, Y. J. (2012). Ecological footprint of Taiwan: A discussion of its implications for urban and rural sustainable development. Computers, Environment and Urban Systems, 36(4), 342-349.

[16] Baabou, W., Grunewald, N., Ouellet-Plamondon, C., Gressot, M., \& Galli, A. (2017). The Ecological Footprint of Mediterranean cities: Awareness creation and policy implications. Environmental Science \& Policy, 69, 94-104.

[17] Li, T., \& Wen, X. (2017). Local ecological footprint dynamics in the construction of the Three Gorges Dam. Resources, Conservation and Recycling.
[18] Toth, G., \& Szigeti, C. (2016). The historical ecological footprint: From over-population to over-consumption. Ecological Indicators, 60, 283-291.

[19] Comino, J. R., Senciales, J. M., Ramos, M. C., Martínez-Casasnovas, J. A., Lasanta, T., Brevik, E. C., ... \& Sinoga, J. R. (2017). Understanding soil erosion processes in Mediterranean sloping vineyards (Montes de Málaga, Spain). Geoderma, 296, 47-59.

[20] Chu, X., Deng, X., Jin, G., Wang, Z., \& Li, Z. (2017). Ecological security assessment based on ecological footprint approach in BeijingTianjin-Hebei region, China. Physics and Chemistry of the Earth, Parts A/B/C, 101, 4351. 